\title{
Forhæfing, undirbúningur sjúklinga fyrir liðskiptaaðgerðir
}

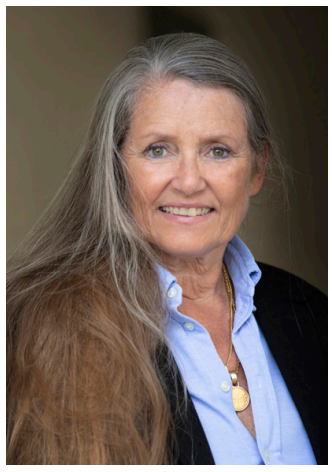

María

\section{Sigurðardóttir}

Sérfræðingur í svæfingaog gjörgæslulækningum á Landspítala

Prehabilitation of patients for arthroplastic surgery. A new patient pathway

María Sigurðardóttir MD, Department of Anaesthesiology and Critical Care, Landspitali University Hospital
Á síðastliðnum áratug hefur orðið mikil breyting á ferli sjúklinga sem gangast undir aðgerðir á Landspítala. Breytingarnar eru til komnar í kjölfar framfara í skurð- og svæfingatækni en einnig vegna niðurskurðar og skorts á skurðstofurými og leguplássum. Pannig hefur dagaðgerðum fjölgað verulega og legutími sjúklinga sem parfnast innlagnar styst. Prátt fyrir pað hefur bið sjúklinga eftir vissum tegundum aðgerða lengst.

Í eldra ferlinu fóru sjúklingar í pörf á liðskiptaaðgerð á biðlista til aðgerðar eftir að ákvörðun hafði verið tekin um aðgerð af bæklunarlækni á göngudeild. Eftir að biðinni lauk komu sjúklingarnir síðan á innskriftarmiðstöð til mats hjá svæfingalækni um pað bil viku fyrir aðgerð, og mættu svo á sjúkrahúsið að morgni aðgerðardags. Eftirlit eftir aðgerðina á sér svo stað á göngudeild.

Fram til pessa hefur biðtíminn frá pví að aðgerð er ákveðin að jafnaði ekki verið notaður á virkan hátt til að undirbúa sjúkling fyrir aðgerð. Reglulega kemur fyrir að fresta purfi aðgerðum sjúklinga pegar í ljós kemur að bæta parf ástand og meðferð sjúklinga fyrir aðgerð. petta getur sett skipulag skurðaðgerða úr skorðum, sem er hvorki æskilegt fyrir sjúklingana né sjúkrahúsið. Með breyttum ferlum sjúklinga par sem lögð er áhersla á að vera á sjúkrahúsi sé sem styst er pörf á nýrri nálgun varðandi undirbúning sjúklinga fyrir aðgerð. Nauðsynlegt er að tengja betur starfsemi og upplýsingaflæði milli heilsugæslu og sjúkrahúss til að framkalla heildræna nálgun í meðferð og eftirliti með sjúklingum.

Á seinustu árum hafa rannsóknir einnig sýnt mikilvægi forhæfingar, pað er undirbúnings fyrir aðgerð til að bæta árangur hennar, minnka líkur á fylgikvillum og stytta legutímaํ. Pví er augljóst að best væri að nýta biðtímann til að undirbúa sjúklinga fyrir aðgerðina. Á peim tíma eru sjúklingarnir oft mjög móttækilegir fyrir ráðleggingum um leiðir til að bæta líkamlegt ástand sitt og breyta lífsstíl svo aðgerðin sem peir bíða eftir heppnist sem best.

Af pessum ástæðum hafa Landspítali og Heilsugæslan (HH, HSU, HSS, HVE, HVEST) hafið samvinnu um undirbúning sjúklinga fyrir liðskiptaaðgerðir, par sem markmiðið er að greina og meðhöndla pekkta áhættupætti tímanlega til að bæta heilsufar sjúklinga fyrir aðgerð og minnka líkur á fylgikvillum, í peirri von að bæta útkomu aðgerðarinnar. Eftir tilvísun frá heilsugæslulækni á göngu- deild bæklunarlækna á Landspítala fer fram upphafsskimun fyrir áhættupáttum um leið og aðgerð er ákveðin. Á meðan leiðir Heilsugæslan meðferð áhættupáttanna, í samvinnu við Landspítala par sem pað á við. Aðkoma Heilsugæslunnar er gríðarlega mikilvæg pví fjölmargir einstaklingar sem koma til aðgerðar hafa marga langvinna sjúkdóma og flókna sjúkdómsmynd, sem Heilsugæslan hefur besta yfirsýn yfir og er best í stakk búin að samræma vinnu annarra aðila innan heilbrigðiskerfisins.

Peir áhættupættir sem áhersla verður lögð á í upphafi eru blóðskortur, sykursýki, vannæring, ofpyngd og reykingar. ${ }^{2-5}$

Með pví að bæta pekkta áhættupætti í aðdraganda aðgerðar vonumst við til að bæta útkomu aðgerðarinnar með fækkun fylgikvilla eins og sárasýkinga, sáragliðnunar, blæðinga, liðlosunar, liðsýkinga og annarra fylgikvilla legunnar á borð við blóðtappa og lungnareks.

Til að meta árangur af pessu breytta ferli sjúklinga hafa samstarfsaðilar, að fengnum nauðsynlegum leyfum, sett petta upp sem rannsóknarverkefni par sem sjúklingum verður fylgt eftir í endurkomu Landspítala sex vikum og svo aftur tveimur árum eftir aðgerð. Blóðprufum, líkamspyngdarstuðli, hreyfingu, næringarástandi og reykingastoppi verður fylgt eftir.

Petta er í fyrsta sinn sem samstarf milli Landspítala og Heilsugæslunnar er skipulagt með pessum hætti. Pað er von okkar að slík samvinna við undirbúning sjúklinga til aðgerðar leiði í ljós styrk pessa fyrirkomulags og skili sjúklingum bættri heilsu, öruggara aðgerðarferli og bættri útkomu eftir aðgerðina. Ef sú verður raunin gæti verkefnið orðið fyrirmynd um nálgun heilbrigðiskerfisins við meðferð annarra sjúkdóma og undirbúning annarra aðgerða.

\section{Heimildir}

1. Venetia Wynter-Blyth, Krishna Moorthy. Prehabilitation: preparing patients for surgery. BMJ 2017;358:j3702 doi:10.1136/bmj.j3702

2. Baron DM et al. Preoperative anaemia is associated with poor clinical outcome in non-cardiac surgery patients. Br J Anaesth. 2014 Sep;113(3):416-23. doi: 10.1093/bja/aeu098. Epub 2014 May 14

3. NIH Classification of Overweight and Obesity by BMI, Waist Circumference, and Associated Disease Risks

4. Anne LÜBBEKE et al. Body mass and weight thresholds for increased prosthetic joint infection rates after primary total joint arthroplasty. Acta Orthopaedica 2016; 87 (2): 132-8

5. Ann M. Møller et al. Effect of smoking on early complications after elective orthopaedic surgery. J Bone Joint Surg [Br] 2003;85-B:178-81. 